\title{
PENGUJIAN BIOFUNGISIDA BERBASIS MIKROORGANISME ANTAGONIS UNTUK PENGENDALIAN PENYAKIT JAMUR AKAR PUTIH PADA TANAMAN KARET
}

\author{
Control of White Root Disease on Hevea Rubber Plants by Using \\ Antagonistic Microorganisms Based Biofungicide
}

\author{
Alchemi Putri Juliantika KUSDIANA, Misbakhul MUNIR, dan Heru SURYANINGTYAS \\ Balai Penelitian Sembawa, Pusat Penelitian Karet \\ Jalan Raya Palembang - Pangkalan Balai KM 29, PO BOX 1127 Palembang 30001 \\ E-mail : alchemiputri@yahoo.com
}

Diterima : 28 April 2015 / Direvisi : 28 Agustus 2015 / Disetujui : 10 September 2015

\begin{abstract}
White root disease (WRD) is one of the important disease in Indonesian rubber plantation because it often causes plant death and lead to significant economic loss. One attempt of the WRD control is treatment of infected plants by biofungicides application. This experiment was carried out to determine the effectiveness of biofungicides with active material of antagonists microbial to control WRD on laboratory scale, greenhouse, and field. This experiment was carried out at Sembawa Research Centre from July 2012 until April 2013. The main material used in this experiment was microbial agent consisting of antagonistic fungi of Trichoderma viridae, $\mathrm{T}$. harzianum, Paecilomyces lilacinus, and antagonistic bacteria of Bacillus subtilis. This experiment was divided into three main steps. The first step was in vitro antagonist test of biofungicides against R. microporus using dual culture method. Second was test, efficacy of biofungicides againts WRD in rubber plants (polybag) of clone PB 260 in the greenhouse using completely randomized design with six treatments and three replications consisting of biofungicide + biofertilizer (active ingredient is mycorrhizae) combinations and chemical fungicides treatments. The last step was efficacy test of biofungicides againts WRD in immature rubber plants of clone $P B$ 260 in the field using randomized block design with nine treatments and three replications consisting of several biofungicides treatments and chemical fungicides treatment. In vitro antagonist test showed that the biofungicides was able to inhibit the growth of R. microporus with an average of $57.62 \%$. Experiment in the greenhouse showed that combinations of biofungicides $100 \mathrm{~g}$ and biofertilizers $200 \mathrm{~g}$ effectively decreased the disease intensity by $5.56 \%$ and it could increase the plant growth, shown by better plant root growth, plant height, and dry biomass. The field experiment of biofungicides application showed that the decrease of disease intensity reduced by $18.33 \%$ to $23.33 \%$ that was not signifficantly
\end{abstract}

different compared with chemical fungicides treatment. Treatment of biofungicides $20 \mathrm{~g} /$ tree resulted in highest decrease in disease intensity compared with other biofungicide treatments. This research concluded that under various studies (in vitro, greenhouse, and field conditions), the biofungicides application was a very promising technique that could be effectively used to control white root disease in rubber plants.

Keywords: Rubber plant, white root disease, Rigidoporus microporus biofungicides

\section{Abstrak}

Penyakit jamur akar putih (JAP) merupakan salah satu penyakit penting di perkebunan karet Indonesia karena dapat menyebabkan kematian tanaman dan kerugian ekonomi yang cukup tinggi. Salah satu usaha pengendalian penyakit JAP adalah pengobatan tanaman sakit dengan menggunakan biofungisida. Tujuan dari pengujian ini untuk mengetahui efektivitas biofungisida berbahan aktif beberapa mikroorganisme antagonis terhadap penyakit JAP pada skala laboratorium, rumah kaca, dan lapangan. Penelitian dilaksanakan di Balai Penelitian Sembawa mulai Juli 2012 sampai April 2013. Bahan utama yang digunakan pada penelitian ini adalah formulasi biofungisida yang mengandung cendawan antagonis Trichoderma viridae, T. harzianum, Paecilomyces lilacinus, dan bakteri antagonis Bacillus subtilis. Percobaan terdiri dari tiga kegiatan yaitu pengujian antagonisme formulasi biofungisida terhadap $R$. microporus di laboratorium dengan menggunakan metode uji ganda, studi efektivitas formulasi biofungisida terhadap penyakit JAP pada bibit karet dalam polibeg klon PB 260 di rumah kaca dengan menggunakan rancangan acak lengkap enam perlakuan dan tiga ulangan yang terdiri dari
\end{abstract}


kombinasi biofungisida + pupuk hayati berbahan aktif mikoriza serta perlakuan fungisida kimia sebagai pembanding, dan studi efektivitas formulasi biofungisida terhadap penyakit JAP pada tanaman karet belum menghasilkan klon PB 260 di lapangan dengan menggunakan rancangan acak kelompok sembilan perlakuan dan tiga ulangan yang terdiri dari beberapa perlakuan biofungisida dan fungisida kimia pembanding. Hasil penelitian di laboratorium menunjukkan biofungisida mampu menekan perkembangan $R$. microporus dengan rata-rata penghambatan sebesar $57,62 \%$. Pengujian di rumah kaca dengan perlakuan kombinasi biofungisida $100 \mathrm{~g}$ dan pupuk hayati $200 \mathrm{~g}$ cukup efektif menurunkan intensitas serangan JAP sebesar 5,56\% dan mampu meningkatkan pertumbuhan tanaman yang terlihat dari pertumbuhan akar, tinggi tanaman, dan biomassa kering yang lebih baik dibandingkan dengan perlakuan lain. Pengujian biofungisida pada TBM menunjukkan penurunan intensitas serangan penyakit sebesar $18,33 \%$ sampai dengan 23,33\% yang tidak berbeda nyata dengan fungisida kimia pembanding dan perlakuan biofungisida $20 \mathrm{~g} /$ pohon memiliki penurunan intensitas serangan penyakit paling tinggi dibandingkan perlakuan biofungisida lainnya. Dari ketiga pengujian menunjukan biofungisida tersebut efektif digunakan untuk mengendalikan penyakit JAP.

Kata kunci: Tanaman karet, jamur akar putih, Rigidoporus microporus, biofungisida

\section{PENDAHULUAN}

Penyakit jamur akar putih (JAP) yang disebabkan oleh cendawan Rigidoporus microporus merupakan penyakit akar paling penting karena sering menyebabkan kerugian ekonomi yang signifikan (Situmorang dan Budiman, 2003). Penyakit JAP telah menjadi penyakit akar yang paling merusak pada pohon karet baik di benua Afrika maupun Asia yang memasok 98\% hasil karet ke pasar dunia. Secara keseluruhan, sekitar 5-10\% dari lahan karet yang dibudidayakan terserang penyakit jamur akar putih dengan negara yang paling terkena dampak saat ini terutama Malaysia, Thailand, Sri Lanka, Filipina, dan Nigeria (Jayasinghe, 2011). Penyakit tersebut dapat menimbulkan kerusakan di kebun entres, tanaman belum menghasilkan, dan tanaman menghasilkan. Kerusakan berat sering terjadi pada tanaman belum menghasilkan. Kematian tanaman mengakibatkan rendahnya kerapatan pohon karet per hektar yang berpengaruh langsung terhadap produktivitas kebun karet (Situmorang, 2004).

Salah satu usaha pengendalian penyakit JAP adalah pengobatan tanaman sakit dengan menggunakan fungisida. Fungisida yang digunakan dapat berupa fungisida kimia, maupun fungisida hayati. Namun, tindakan pengobatan pada tanaman yang terinfeksi jamur akar putih sangat jarang dilakukan, terutama di perkebunan karet rakyat karena biaya pengobatan yang terlalu tinggi (Situmorang dan Suryaningtyas, 2007). Biaya yang tinggi tersebut dapat disebabkan karena fungisida harus diaplikasikan dengan interval tertentu dan/atau tingkat keefektifan fungisida dalam mengendalikan serangan jamur akar putih masih tergolong rendah.

Perlindungan tanaman dengan menggunakan fungisida hayati atau lebih dikenal dengan biofungisida merupakan perlindungan terhadap patogen tanaman oleh mikroorganisme antagonis termasuk penyebaran pada saat sebelum atau setelah terjadinya infeksi patogen. Mekanisme biokontrol organisme dalam melemahkan atau membunuh patogen yaitu dengan memparasit patogen secara langsung, memproduksi antibiotik (toksin), dan kompetisi ruang dan nutrisi, memproduksi enzim untuk melawan komponen sel patogen, menginduksi respon ketahanan tanaman, dan memproduksi metabolit tanaman dalam menstimulasi perkecambahan spora patogen (Agrios, 2005).

Biofungisida terdiri dari mikroorganisme yang menguntungkan, seperti cendawan dan bakteri yang dapat menyerang dan mengendalikan patogen penyebab penyakit pada tanaman. Biofungisida menjadi alternatif untuk mengurangi penggunaan fungisida kimia yang dapat menyebabkan dampak negatif bagi kesehatan manusia dan lingkungan (Gavrilescu dan Chisti, 2005), serta menyebabkan patogen mengembangkan ras baru yang lebih rentan (Agrios, 2005; Benitez et al., 2004).

Menurut Benitez et al. (2004), agen biokontrol terutama cendawan antagonis dapat digunakan untuk mengendalikan penyakit tanaman sampai $90 \%$ dengan 
aplikasi berupa formulasi yang menggunakan beberapa strains Trichoderma, seperti T. harzianum, T. virens, dan $T$. viridae. Hasil penelitian Amaria et al. (2013) menunjukkan bahwa cendawan $T$. harzianum, $T$. viridae, dan $P$. lilacinus merupakan cendawan antagonis potensial untuk mengendalikan penyakit jamur akar putih pada tanaman karet. Hasil penelitian Morsy et al. (2009) dan Liu et al. (2009) memperlihatkan bahwa kombinasi cendawan Trichoderma dan B. subtilis dapat mengendalikan penyakit akar.

Selain itu, hasil penelitian Pusat Penelitian Karet dengan fungisida hayati Endohevea berbahan aktif $T$. koninggi, $T$. viridae, dan T. harzianum dengan dosis satu tablet/ lima tanaman dengan pengulangan aplikasi setiap tiga bulan mampu mengendalikan penyakit jamur akar putih dengan persentase kesembuhan penyakit sebesar 78,94\% (Fairuzah et al., 2014). Fungisida hayati lainnya Triko SP $\mathrm{SP}^{\text {plus }}$ berbahan aktif Trichoderma spp. mampu menghambat perkembangan JAP sebesar $60 \%$ pada bibit karet polibag di rumah kaca (Fairuzah dan Karyudi, 2010). Pengujian fungisida hayati Triko Combi berbahan aktif T. viridae, T. koningii, T. harzianum, dan satu strain lokal Trichoderma spp. dengan dosis $10 \mathrm{~g} /$ polibag di rumah kaca mampu mengurangi intensitas serangan penyakit menjadi 20\% dibandingkan dengan kontrol tanpa aplikasi sebesar 40\% (Setyawan, 2013). Tujuan dari pengujian ini yaitu untuk mengetahui efektivitas biofungisida berbahan aktif mikroba (hayati) pada skala laboratorium, rumah kaca, dan lapangan.

\section{BAHAN DAN METODE}

Penelitian dilaksanakan di Balai Penelitian Sembawa mulai Juli 2012 sampai dengan April 2013. Formulasi biofungisida yang digunakan mengandung cendawan antagonis Trichoderma viridae, $T$. harzianum, Paecilomyces lilacinus, dan bakteri antagonis Bacillus subtilis. Sedangkan sebagai pembanding digunakan Trichoderma spp, serta fungisida kimia berbahan aktif triadimefon dan triadimenol. Percobaan ini terdiri dari tiga kegiatan yaitu: (1) studi in vitro antagonisme formulasi biofungisida terhadap cendawan $R$. microporus di laboratorium; (2) studi efektivitas formulasi biofungisida terhadap penyakit JAP pada bibit karet dalam polibeg; dan (3) studi efektivitas formulasi biofungisida terhadap penyakit JAP pada tanaman karet belum menghasilkan (TBM) di lapangan. Secara rinci metode yang digunakan pada masing-masing kegiatan tersebut sebagai berikut:

\section{Studi in vitro Antagonisme Biofungisida terhadap $R$. microporus}

\section{Persiapan inokulum $R$. microporus}

Biakan isolat $R$. microporus dibuat dengan cara mengambil bagian akar yang terserang penyakit jamur akar putih dari lapangan. Bagian dari akar tersebut diisolasi pada media PDA (potato dextrose agar), kemudian apabila sudah tumbuh miselia cendawan dilakukan pemurnian isolat. Biakan murni $R$. microporus diremajakan dengan membuat inokulum cendawan berbentuk lempengan berdiamater $0,5 \mathrm{~cm}$ setebal $1-2 \mathrm{~mm}$, dengan bantuan cork borer steril yang selanjutnya diinokulasikan tepat di tengah medium agar.

\section{Uji antagonisme}

Uji in vitro antagonisme antara formulasi biofungisida dengan $R$. microporus sebagai patogen dilakukan menggunakan metode uji ganda (dual culture) pada cawan petri yang berisi media PDA. Setiap perlakuan terdiri atas ulangan 10 cawan petri, dengan ukuran diameter $9 \mathrm{~cm}$. Inokulum dari biofungisida diinokulasikan pada media dengan jarak $1 \mathrm{~cm}$ dari bagian tepi cawan, sedangkan inokulum cendawan $R$. microporus ditempatkan pada jarak $1 \mathrm{~cm}$ dari bagian tepi cawan petri pada sisi lain. Sebagai kontrol, dilakukan inokulasi $R$. microporus, tanpa diinokulasikan biofungisida. Selanjutnya cawan petri tersebut diinkubasi pada suhu ruang selama enam hari.

Pengamatan dilakukan dengan mengukur pertumbuhan $R$. microporus ke arah biofungisida serta jarak kedua inokulum. Pengamatan interaksi antagonisme dilakukan pada enam hari setelah inokulasi. 


\section{Studi Efektivitas Biofungisida terhadap Penyakit JAP pada Bibit Karet dalam Polibeg}

Pengujian efektivitas formulasi biofungisida terhadap penyakit JAP pada bibit karet dalam polibeg dilakukan di rumah kaca selama enam bulan, mulai Juli sampai dengan Desember 2012. Bibit karet yang digunakan adalah klon PB 260 pada stadia tumbuh satu payung daun. Pada penelitian ini digunakan perlakuan biofungisida yang dikombinasikan dengan pupuk hayati dengan tujuan untuk meningkatkan pertumbuhan tanaman. Pupuk hayati yang digunakan berupa formulasi mikoriza dengan kandungan beberapa mikoriza, seperti Acaulospora bireticulata, A. leavis, Gigaspora margarita, G. rosea, Glomus clarum, G. etunicatum, G. fasciculatum, G. geasporum, G. intraradies, G. mosseae, Scutellospora calospora, dan Sclerocystis pachycaulis. Rancangan percobaan yang digunakan adalah rancangan acak lengkap dengan enam perlakuan dan tiga ulangan sebagai berikut:

1. Biofungisida (10 g/polibeg) + pupuk hayati (200 g/polibeg)

2. Biofungisida (50 g/polibeg) + pupuk hayati (200 g/ polibeg)

3. Biofungisida (100 g/polibeg) + pupuk hayati (200 g/polibeg)

4. Triadimenol (5 g/polibeg)

5. Triadimefon ( $5 \mathrm{cc} /$ polibeg)

6. Kontrol (tanpa perlakuan)

Masing-masing ulangan terdiri atas tiga tanaman sehingga terdapat 54 tanaman contoh.

\section{Aplikasi biofungisida ke bibit polibeg}

Inokulum berupa potongan kayu karet berukuran $13 \mathrm{~cm} \times 3 \mathrm{~cm}$ yang terkolonisasi miselium JAP sebanyak empat buah diintroduksikan ke dalam media tanah di polibeg berukuran $35 \mathrm{~cm} \mathrm{x}$ $50 \mathrm{~cm}$ pada daerah sekitar pangkal akar. Pengamatan terhadap proses infeksi JAP dilakukan hingga tanaman mengalami gejala serangan skala I, yaitu miselium menempel pada permukaan luar akar. Setelah tanaman bergejala JAP skala 1 , dilakukan aplikasi biofungisida sesuai dengan perlakuan. Aplikasi dilakukan sekali dengan cara membenamkan biofungisida tersebut ke dalam media (polibeg) didekat perakaran bibit karet. Selama berlangsungnya percobaan, pemeliharaan tanaman (penyiraman) dilakukan sesuai rekomendasi atau kebutuhan.

Pengamatan perkembangan JAP pasca aplikasi biofungisida

Perkembangan JAP diamati dengan membongkar polibeg dan mengamati perakaran bibit karet enam bulan setelah perlakuan. Keefektifan formula biofungisida ditentukan berdasarkan skala serangan JAP sebagai berikut:

- Skala serangan 0 : tidak ada miselium JAP menempel pada perakaran bibit;

- Skala serangan 1 : terdapat miselium JAP menempel pada perakaran bibit;

- Skala serangan 2 : terdapat miselium JAP menempel pada perakaran bibit dan telah penetrasi ke dalam jaringan;

- Skala serangan 3 : jaringan dalam akar berwarna hitam dan membusuk

- Skala serangan 4 : tanaman telah mati dan akar busuk.

Selanjutnya intensitas serangan penyakit ditentukan dengan rumus sebagai berikut (Townsend dan Heuberger, 1943 dalam Sinaga, 2006):

$$
\mathrm{IP}=\frac{\sum_{i=1}^{n} n \cdot v}{Z . N} \times 100 \%
$$

dengan

$$
\begin{array}{ll}
\text { IP } & \text { : intensitas penyakit; } \\
\mathrm{n} & \text { : jumlah tanaman berskala v; } \\
\mathrm{v} & \text { : skala ke-i; dan } \\
\mathrm{Z} & \text { : nilai skor tertinggi. } \\
\mathrm{N} & \text { :jumlah tanaman yang } \\
& \text { diamati }
\end{array}
$$

Data skala serangan dianalisis menggunakan one way anova dan diuji lanjut menggunakan Duncan Multiple Range Test dalam program Statistical Analysis System (SAS) (Mattjik dan Sumertajaya, 2006). 


\section{Studi Efektivitas Biofungisida terhadap Penyakit JAP pada Tanaman Karet Belum Menghasilkan di Lapangan}

Pengujian efektivitas biofungisida pada tanaman karet belum menghasilkan di lapangan dilakukan selama sembilan bulan mulai Agustus 2012 sampai dengan April 2013. Tanaman karet yang digunakan adalah klon PB 260 berumur 2 tahun dengan jarak tanam $6 \mathrm{~m}$ x $3 \mathrm{~m}$. Secara alami areal pertanaman atau lokasi penelitian tersebut mengalami serangan JAP dengan intensitas cukup tinggi. Sebagai tanaman sampel dipilih pohon yang terserang JAP dengan skala serangan 1 dan 2 . Rancangan percobaan yang digunakan adalah rancangan acak kelompok dengan sembilan perlakuan dan tiga ulangan, sebagai berikut:

1. Biofungisida ( $20 \mathrm{~g} /$ pohon)

2. Biofungisida (40 g/pohon)

3. Biofungisida (100 g/pohon)

4. Biofungisida (200 g/pohon)

5. Biofungisida ( $400 \mathrm{~g} /$ pohon)

6. Triadimenol ( $5 \mathrm{~g} /$ liter air)

7. Triadimefon (5 cc/liter air)

8. Trichoderma spp. (100 g/pohon)

9. Kontrol (tanpa perlakuan)

Masing-masing ulangan terdiri atas lima tanaman contoh sehingga terdapat 135 pohon contoh.

\section{Aplikasi biofungisida ke tanaman karet}

Biofungisida diaplikasikan dengan cara dibenamkan pada empat titik di sekitar pohon karet yang bergejala JAP. Sebagai kontrol terdapat tanaman karet bergejala JAP tanpa aplikasi fungisida dan sebagai pembanding dilakukan aplikasi fungisida kimia berbahan aktif triadimenol, triadimefon, dan biofungisida berbahan aktif Trichoderma spp. Aplikasi biofungisida dilakukan dua kali dengan frekuensi enam bulan sekali.

Pengamatan perkembangan JAP pasca aplikasi biofungisida

Pengamatan perkembangan JAP dilakukan tiga bulan sekali selama sembilan bulan dengan membongkar bagian pangkal akar, serta perakaran karet. Keefektifan formula biofungisida ditentukan berdasarkan skala serangan sebagai berikut
- Skala serangan 0 : tidak ada miselium JAP menempel pada perakaran;

- Skala serangan 1 : terdapat miselium JAP menempel pada perakaran;

- Skala serangan 2 : terdapat miselium JAP menempel pada perakaran dan telah penetrasi ke dalam jaringan;

- Skala serangan 3 : jaringan dalam akar berwarna hitam dan membusuk

- Skala serangan 4 : tanaman telah mati dan akar busuk.

Selanjutnya intensitas serangan penyakit ditentukan dengan rumus sebagai berikut: (Townsend dan Heuberger, 1943 dalam Sinaga, 2006).

$$
\mathrm{IP}=\frac{\sum_{i=1}^{n} n \cdot v}{Z . N} \times 100 \%
$$

dengan

IP : intensitas penyakit;

$\mathrm{n}$ : jumlah tanaman berskala v;

$\mathrm{v}$ : skala ke-i; dan

$\mathrm{Z} \quad$ : nilai skor tertinggi.

$\mathrm{N} \quad$ :jumlah tanaman yang diamati

Data skala serangan dianalisis menggunakan one way anova dan diuji lanjut menggunakan Duncan Multiple Range Test dalam program Statistical Analysis System (SAS) (Mattjik dan Sumertajaya, 2006).

\section{HASIL DAN PEMBAHASAN}

\section{Studi in vitro Antagonisme Biofungisida terhadap R. microporus}

Uji antagonisme secara in vitro antara cendawan $R$. microporus dengan biofungisida berbasis mikroorganisme antagonis dilakukan di Laboratorium Proteksi, Balai Penelitian Sembawa dengan parameter pengamatan berupa pertumbuhan jari-jari $R$. microporus dan persentase penghambatan biofungisida terhadap cendawan $R$. microporus (Tabel 1).

Hasil pengamatan menunjukkan bahwa pertumbuhan $R$. microporus pada 
Tabel 1. Pertumbuhan miselium $R$. microporus $(\mathrm{cm})$ pada masing-masing perlakuan dan persentase penghambatan $R$. microporus oleh biofungisida

Table 1. Mycelium growth of R. microporus $(\mathrm{cm})$ in each treatments and percentage of growt inhibition of R. microporus by biofungicides

\begin{tabular}{cccc}
\hline \multirow{2}{*}{$\begin{array}{c}\text { Ulangan } \\
\text { Replications }\end{array}$} & \multicolumn{2}{c}{$\begin{array}{c}\text { Perlakuan } \\
\text { Treatments }\end{array}$} & $\begin{array}{c}\text { Penghambatan } \\
\text { R. microporus } \\
\text { Growth Inhibition of } \\
\text { R. microporus } \\
(\%)\end{array}$ \\
\cline { 2 - 4 } & $\begin{array}{c}\text { R. microporus + biofungisida } \\
1\end{array}$ & R. microporus & 50,00 \\
2 & 1,80 & 3,60 & 47,22 \\
3 & 1,90 & 3,60 & 58,33 \\
4 & 1,50 & 3,60 & 56,10 \\
5 & 1,80 & 4,10 & 58,97 \\
6 & 1,60 & 3,90 & 52,50 \\
7 & 1,90 & 4,00 & 52,38 \\
8 & 2,00 & 4,20 & 57,14 \\
9 & 1,50 & 3,50 & 81,40 \\
10 & 0,80 & 4,30 & 62,16 \\
\hline Rata-rata & 1,40 & 3,70 & $\mathbf{5 7 , 6 2}$ \\
\hline * Angka-angka yang diikuti huruf yang sama tidak berbeda nyata menurut uji Jarak \\
Berganda Duncan pada taraf 5\% & $\mathbf{3 , 8 5 \mathbf { b }}$ \\
* Values followed by the same letter are not significantly different according to Duncan \\
Multiple Range test at 5\% level
\end{tabular}

perlakuan biofungisida berbeda nyata dengan kontrol (tanpa biofungisida). Pertumbuhan miselium $R$. microporus pada perlakuan biofungisida memiliki rata-rata ukuran jari-jari sebesar $1,62 \mathrm{~cm}$, yaitu lebih pendek dibandingkan dengan kontrol (tanpa biofungisida), dimana rata-rata ukuran jarijarinya sebesar $3,85 \mathrm{~cm}$ atau berkisar 3,50 $4,30 \mathrm{~cm}$. Hal ini menunjukkan bahwa biofungisida pada pengujian secara in vitro di laboratorium terbukti efektif dapat menghambat perkembangan cendawan $R$. microporus rata-rata sebesar $57,62 \%$, atau berkisar 47,22\%-81,40\%. Hasil penelitian serupa juga dikemukakan oleh Amaria et al. (2013) bahwa agen antagonis Trichoderma spp. dan Paecilomyces lilacinus efektif menghambat perkembangan $R$. microporus secara in vitro dengan persentase daya hambat lebih dari $70 \%$. Hasil penelitian Muharni dan Widjajanti (2011) juga mengatakan bahwa agen antagonis genus Bacillus sp. efektif menghambat perkembangan $R$. microporus penyebab penyakit jamur akar putih pada tanaman karet. Hasil pengujian Triko Combi di laboratorium menunjukkan hasil pertumbuhan miselium $R$. microporus pada perlakuan Trichoderma sp. memiliki ratarata ukuran jari-jari sebesar 2,05 cm dibandingkan dengan kontrol sebesar 7,99 cm (Setyawan, 2013). Selain itu, pengujian Triko $\mathrm{SP}^{\text {plus }}$ secara in vitro di laboratorium memiliki persentase penghambatan terhadap kontrol sebesar 71,29\% (Fairuzah dan Karyudi, 2010).

Pertumbuhan miselium cendawan $R$. microporus secara nyata terhambat oleh pertumbuhan miselium biofungisida. Hal ini terlihat dari lebar koloni $R$. microporus lebih kecil dibandingkan koloni dari biofungisida (Gambar 1A). Pertumbuhan miselium cendawan $R$. microporus pada perlakuan $R$. microporus + biofungisida berkisar 0,80 $2,00 \mathrm{~cm}$ dengan rata-rata pertumbuhan miselium $1,62 \mathrm{~cm}$. Berbeda dengan perlakuan kontrol, miselium $R$. microporus terus tumbuh tanpa adanya hambatan (Gambar 1B), dengan pertumbuhan miselium cendawan $R$. microporus berkisar antara $3,50-4,20 \mathrm{~cm}$ dengan rata-rata pertumbuhan miselium $3,85 \mathrm{~cm}$. Dari kedua perlakuan tersebut, persentase 


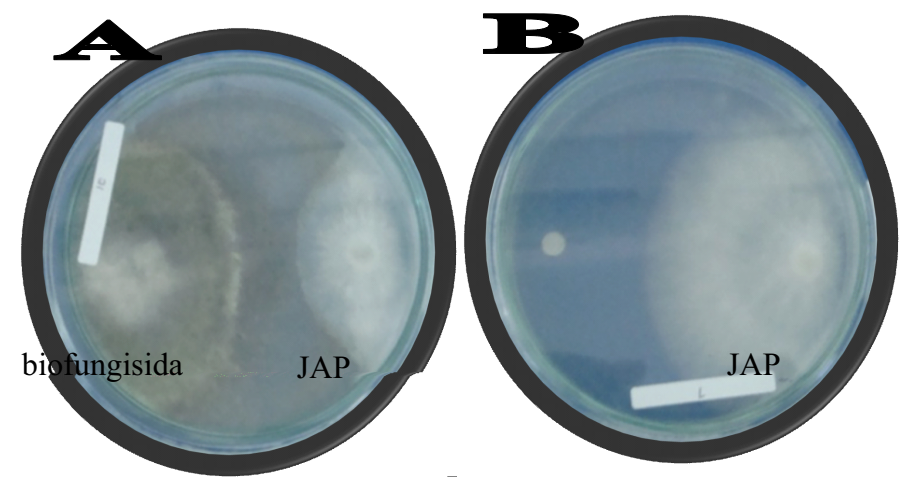

Gambar 1. Perlakuan R. microporus + biofungisida (A) dan perlakuan kontrol (B) pada enam hari setelah inokulasi

Figure 1. R. microporus + biofungicides treatments (A) and untreated control treatments (B), six days afterinoculation

penghambatan biofungisida terhadap cendawan $R$. microporus berkisar 47,22 $81,40 \%$ dengan rata-rata persentase penghambatan sebesar $57,62 \%$. Salah satu syarat untuk organisme disebut sebagai agens hayati adalah apabila mempunyai kemampuan menghambat perkembangan dan pertumbuhan organisme lain (Cook dan Baker, 1983).

\section{Studi Efektivitas Biofungisida terhadap Penyakit JAP pada Bibit Karet dalam Polibeg}

Pada kegiatan ini, aplikasi biofungisida pada bibit karet polibeg di rumah kaca disertai dengan aplikasi pupuk hayati berbahan aktif mikoriza. Hal ini dengan pertimbangan bahwa pupuk hayati dapat meningkatkan penyerapan nutrisi pada tanaman (Hart dan Trevors, 2005).

Tabel 2 menunjukkan nilai perubahan intensitas serangan penyakit pada enam bulan setelah perlakuan. Beberapa perlakuan mengalami penurunan intensitas serangan penyakit berkisar antara 2,78 - 22,22\%. Hal ini berbeda dengan kontrol yang mengalami kenaikan intensitas serangan penyakit sebesar 8,33\%. Namun, terdapat satu perlakuan biofungisida yang mengalami kenaikan intensitas serangan penyakit yaitu perlakuan biofungisida $50 \mathrm{~g}+$ pupuk hayati $200 \mathrm{~g}$ memiliki kenaikan intensitas serangan penyakit sebesar 5,56\%. Kenaikan intensitas serangan penyakit tersebut dapat disebabkan oleh faktor yang mempengaruhi fungisida hayati di lapangan, misalnya hasil yang diperoleh lambat dan tidak konsisten. Fungisida hayati mengandung bahan aktif berupa mikroorganisme hidup yang efektivitas fungisidanya akan tercapai apabila waktu, metode, penanganan, dan penyimpanan fungisida dilakukan dengan benar (Rahayu, 2007).

Secara visual dapat dilihat pada Gambar 2 bahwa pertumbuhan akar tanaman pada perlakuan biofungisida + pupuk hayati (Gambar 2A) lebih lebat dibandingkan pertumbuhan akar tanaman pada perlakuan fungisida kimia (Gambar 2B). Hal tersebut membuktikan bahwa pupuk hayati berpotensi meningkatkan pertumbuhan tanaman melalui penguatan pertumbuhan akar. Menurut Gaur dan Adholeya (2004), pupuk hayati terdiri dari mikroba yang dapat meningkatkan kesuburan tanah dan produktivitas hasil, seperti mikoriza. Mikoriza adalah cendawan yang memiliki simbiosis mutualisme dengan akar tanaman. Mikoriza dapat meningkatkan penyerapan nutrisi dan air, mengendalikan penyakit tanaman, dan meningkatkan struktur tanah. Tanaman yang berkolonisasi dengan mikoriza tumbuh lebih baik daripada tanaman tanpa kolonisasi mikoriza (Yeasmin et al., 2007).

Selain keragaan akar tanaman, biomassa tanaman juga diamati untuk 
Tabel 2. Perkembangan intensitas serangan penyakit JAP pada enam bulan setelah aplikasi (bsa)

Table 2. Development of WRD disease intensity, six months after treatments (mat)

\begin{tabular}{|c|c|c|c|c|}
\hline \multirow[t]{2}{*}{ No. } & \multirow[t]{2}{*}{$\begin{array}{l}\text { Perlakuan } \\
\text { Treatments }\end{array}$} & \multicolumn{2}{|c|}{$\begin{array}{c}\text { Intensitas serangan } \\
\text { penyakit } \\
\text { Disease intensity } \\
(\%) \\
\end{array}$} & \multirow{2}{*}{$\begin{array}{c}\text { Perubahan } \\
\text { intensitas serangan } \\
\text { penyakit } \\
\text { Decrease/increase } \\
\text { in disease intensity }\end{array}$} \\
\hline & & $\begin{array}{l}0 \text { bsa } \\
0 \text { mat }\end{array}$ & $\begin{array}{l}6 \mathrm{bsa}^{*} \\
6 \mathrm{mat}\end{array}$ & \\
\hline & Biofungisida $10 \mathrm{~g}+$ pupuk hayati $200 \mathrm{~g}$ & 25,00 & $22,22 \mathrm{ab}$ & 2,78 \\
\hline & Biofungisida $50 \mathrm{~g}+$ pupuk hayati $200 \mathrm{~g}$ & 25,00 & $30,56 a b$ & $(+) \quad 5,56$ \\
\hline 3. & Biofungisida $100 \mathrm{~g}+$ pupuk hayati $200 \mathrm{~g}$ & 25,00 & $19,44 a b$ & 5,56 \\
\hline & Triadimenol $5 \mathrm{~g} /$ polibeg & 25,00 & $16,67 \mathrm{bc}$ & 8,33 \\
\hline & Triadimefon $5 \mathrm{cc} / 1$ air & 25,00 & $2,78 \mathrm{c}$ & $(-) \quad 22,22$ \\
\hline & Kontrol & 25,00 & $33,33 a$ & $(+) \quad 8,33$ \\
\hline
\end{tabular}

* Angka-angka yang diikuti huruf yang sama tidak berbeda nyata menurut uji Jarak Berganda Duncan pada taraf 5\%

* Values followed by the same letter are not significantly different according to Duncan Multiple Range test at $5 \%$ level

** $(-)=$ intensitas serangan penyakit turun (ada proses penyembuhan atau ada penurunan skala serangan)

$(+)=$ intensitas serangan penyakit naik (serangan semakin parah atau skala serangan naik)

** $(-)=$ decrease in disease intensity (less severe attack)

$(+)=$ increase in disease intensity (more severe attack)
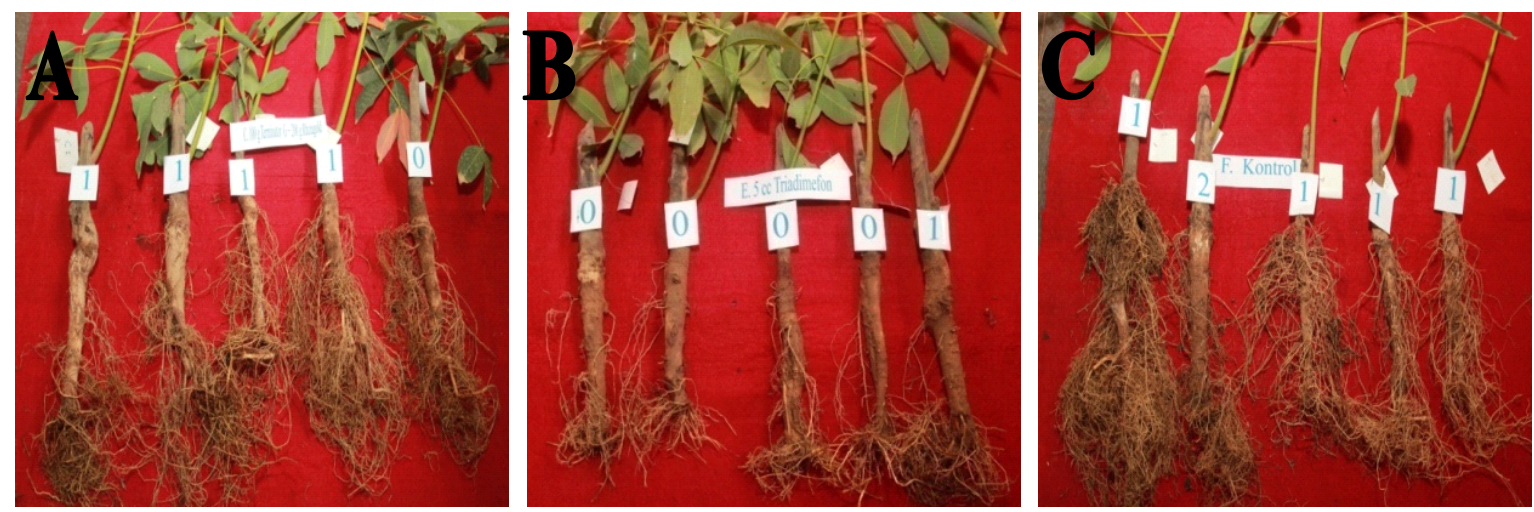

Gambar 2. Keragaan pertumbuhan akar tanaman dalam polibeg pada berbagai perlakuan. (A) biofungisida + pupuk hayati, (B) fungisida kimia (triadimefon 5 cC), (C) kontrol

Figure 2. Root growth performance of rubber plants in each treatments. (A) biofungicides + biofertilizers, (B) chemical fungicides (triadimenol $5 \mathrm{~g}$ ), (C) untreated control 
melihat pengaruh aplikasi pupuk hayati terhadap pertumbuhan tanaman. Hasil pengamatan menunjukkan bahwa pada perlakuan pupuk hayati (Tabel 3), biomassa kering (daun, akar, dan batang) secara nyata lebih tinggi dibandingkan perlakuan lainnya.

Hasil pengamatan menunjukkan biomassa kering daun pada perlakuan biofungisida $100 \mathrm{~g}+$ pupuk hayati $200 \mathrm{~g}$ lebih tinggi dibandingkan perlakuan lainnya, sedangkan perlakuan lainnya memiliki nilai yang tidak berbeda nyata dengan kontrol. Pengamatan biomassa kering akar dan batang menunjukkan nilai yang tidak berbeda nyata dari semua perlakuan dengan kontrol, tetapi perlakuan biofungisida $100 \mathrm{~g}+$ pupuk hayati $200 \mathrm{~g}$ memiliki biomassa yang lebih tinggi. Biomassa total dari perlakuan biofungisida $100 \mathrm{~g}+$ pupuk hayati $200 \mathrm{~g}$ lebih tinggi dibandingkan perlakuan kontrol dan perlakuan lainnya, sedangkan perlakuan kimia (triadimefon) memiliki total biomassa yang lebih kecil dibandingkan perlakuan lainnya.

Tabel 3. Rata-rata biomassa kering tanaman pada enam bulan setelah perlakuan

Table 3. The average of plants biomass, six months after treatments

\begin{tabular}{|c|c|c|c|c|c|}
\hline \multirow{2}{*}{\multicolumn{2}{|c|}{ Perlakuan }} & \multicolumn{4}{|c|}{$\begin{array}{c}\text { Biomassa kering } \\
\text { Plant biomass } \\
\text { (gram) }\end{array}$} \\
\hline & & $\begin{array}{l}\text { Daun } \\
\text { Leaf }\end{array}$ & $\begin{array}{c}\text { Batang } \\
\text { Stem }\end{array}$ & $\begin{array}{l}\text { Akar } \\
\text { Root }\end{array}$ & Total \\
\hline 1. & Biofungisida $10 \mathrm{~g}+$ pupuk hayati $200 \mathrm{~g}$ & $13,27 \mathrm{bc}$ & $11,27 \mathrm{ab}$ & $8,16 \mathrm{ab}$ & $32,71 \mathrm{bc}$ \\
\hline 2. & Biofungisida $50 \mathrm{~g}+$ pupuk hayati $200 \mathrm{~g}$ & $14,46 \mathrm{bc}$ & $13,69 a b$ & $9,42 \mathrm{ab}$ & $37,57 \mathrm{~b}$ \\
\hline 3. & Biofungisida $100 \mathrm{~g}+$ pupuk hayati $200 \mathrm{~g}$ & 25,98 a & $15,58 \mathrm{a}$ & $11,00 \mathrm{a}$ & 52,56 a \\
\hline 4. & Triadimenol $5 \mathrm{~g} /$ polibeg & $18,43 \mathrm{~b}$ & $11,72 \mathrm{ab}$ & $7,81 \mathrm{ab}$ & $37,96 \mathrm{~b}$ \\
\hline 5. & Triadimefon $5 \mathrm{cc} / 1$ air & $10,03 \mathrm{c}$ & $9,90 \mathrm{~b}$ & $6,15 \mathrm{~b}$ & $26,08 \mathrm{c}$ \\
\hline 6. & Kontrol & $14,79 \mathrm{bc}$ & $13,81 \mathrm{ab}$ & $11,83 \mathrm{a}$ & $40,43 \mathrm{~b}$ \\
\hline
\end{tabular}

* Angka-angka yang diikuti huruf yang sama tidak berbeda nyata menurut uji Jarak Berganda Duncan pada taraf $5 \%$

* Values followed by the same letter are not significantly different according to Duncan Multiple Range test at 5\% level

Pada Gambar 3 dapat dilihat bahwa keragaan tinggi tanaman yang diberi biofungisida + pupuk hayati cenderung lebih tinggi dibanding perlakuan fungisida kimia dan kontrol. Hasil penelitian (Tabel 4) juga menunjukkan pertumbuhan tinggi tanaman paling besar yaitu pada perlakuan biofungisida $100 \mathrm{~g}+$ pupuk hayati $200 \mathrm{~g}$, sedangkan perlakuan kontrol berada pada urutan kedua. Perlakuan lainnya memiliki nilai yang tidak berbeda nyata dengan kontrol, kecuali pada perlakuan fungisida berbahan aktif triadimefon yang memiliki nilai pertumbuhan tinggi tanaman paling kecil. Dari hasil biomassa kering dan tinggi tanaman membuktikan bahwa pemberian pupuk hayati dapat meningkatkan pertumbuhan tanaman, yang selanjutnya diharapkan dapat meningkatkan ketahanan tanaman terhadap penyakit.

Menurut Kaewchai et al. (2009), manfaat penggunaan biofungisida dan penambahan pupuk hayati adalah untuk mengurangi terjadinya penyakit tanaman dengan cara menghambat pertumbuhan patogen, menekan jumlah inokulum patogen, meningkatkan penyerapan nutrisi dari tanah atau atmosfer, dan memproduksi senyawa bioaktif, hormon dan enzim yang dapat merangsang pertumbuhan tanaman. Selain itu, dapat mempertahankan dan meningkatkan produksi tanaman. 
Tabel 4. Tinggi tanaman pada enam bulan setelah perlakuan Table 4. Plant height at six months after treatments

\begin{tabular}{cll}
\hline No. & \multicolumn{1}{c}{$\begin{array}{c}\text { Perlakuan } \\
\text { Treatments }\end{array}$} & $\begin{array}{c}\text { Tinggi tanaman } \\
\text { Plant height } \\
\text { (cm) }\end{array}$ \\
\hline 1. & Biofungisida $10 \mathrm{~g}+$ pupuk hayati $200 \mathrm{~g}$ & $69,50 \mathrm{bc}$ \\
2. & Biofungisida $50 \mathrm{~g}+$ pupuk hayati $200 \mathrm{~g}$ & $78,67 \mathrm{abc}$ \\
3. & Biofungisida $100 \mathrm{~g}+$ pupuk hayati $200 \mathrm{~g}$ & $\mathbf{9 4 , 8 3 ~ a}$ \\
4. & Triadimenol $5 \mathrm{~g} /$ polibeg & $78,33 \mathrm{abc}$ \\
5. & Triadimefon $5 \mathrm{cc} / 1$ air & $61,50 \mathrm{c}$ \\
6. & Kontrol & $87,33 \mathrm{ab}$ \\
\hline
\end{tabular}

* Angka-angka yang diikuti huruf yang sama tidak berbeda nyata menurut uji Jarak Berganda Duncan pada taraf 5\%

* Values followed by the same letter are not significantly different according to Duncan Multiple Range test at 5\% level

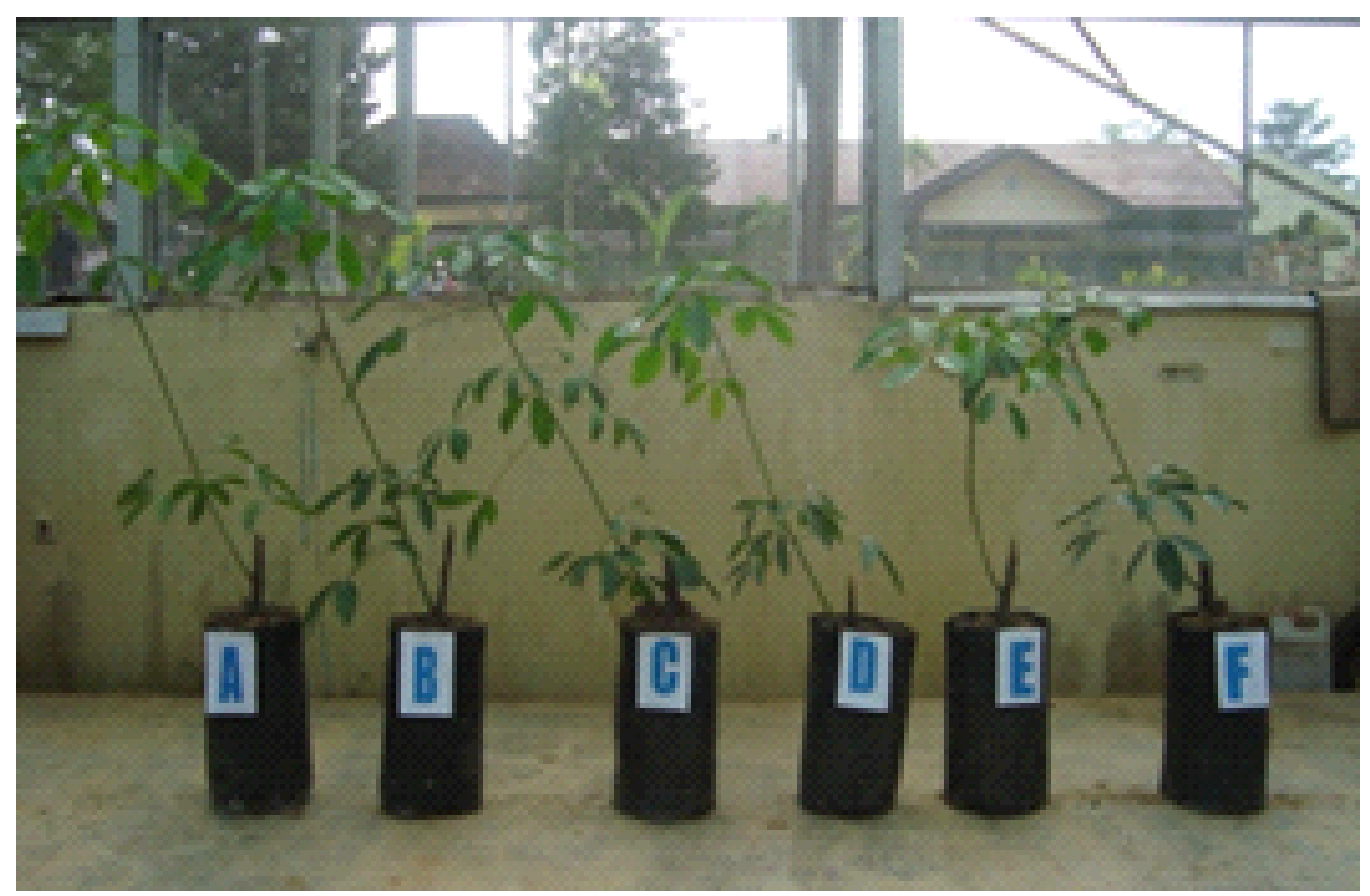

Gambar 3. Keragaan (tinggi) tanaman pada berbagai perlakuan: (A) biofungisida $10 \mathrm{~g}+$ pupuk hayati $200 \mathrm{~g}$, (B) biofungisida $50 \mathrm{~g}+$ pupuk hayati $200 \mathrm{~g}$, (C) biofungisida $100 \mathrm{~g}+$ pupuk hayati $200 \mathrm{~g}$, (D) triadimenol $5 \mathrm{~g}$, (E) triadimefon $5 \mathrm{cc} / 1 \mathrm{tr}$ air, (F) Kontrol

Figure 3. Plant growth performance (plant height) in various treatments. (A) biofungicides $10 \mathrm{~g}+$ biofertilizers $200 \mathrm{~g}$, (B) biofungicides $50 \mathrm{~g}+$ biofertilizers $200 \mathrm{~g}$, (C) biofungicides $100 \mathrm{~g}+$ biofertilizers $200 \mathrm{~g}$, (D) triadimenol $5 \mathrm{~g}$, (E) triadimefon $5 \mathrm{cc} / \mathrm{l}$ water, $(F)$ untreated control 


\section{Studi Efektivitas Biofungisida terhadap Penyakit JAP pada Tanaman Karet Belum Menghasilkan di Lapangan}

Hasil pengamatan perkembangan intensitas serangan JAP pada awal percobaan sampai dengan sembilan bulan setelah perlakuan disajikan pada Tabel 5 .

Pada Tabel 5 terlihat bahwa intensitas serangan penyakit pada semua perlakuan biofungisida sampai dengan sembilan bulan setelah perlakuan terus mengalami penurunan. Secara umum intensitas penyakit pada perlakuan biofungisida dengan berbagai dosis dan perlakuan pembanding (triadimenol, triadimefon, dan Trichoderma spp.) menunjukkan intensitas penyakit yang lebih rendah dibandingkan intensitas penyakit pada awal atau sebelum perlakuan. Sementara pada kontrol, intensitas JAP mengalami kenaikan dibandingkan dengan intensitas awal (Tabel 5). Pada beberapa perlakuan terjadi penurunan intensitas serangan penyakit berkisar antara 4,16\% $25,84 \%$, berbeda dengan kontrol yang mengalami kenaikan intensitas serangan penyakit sebesar $26,67 \%$. Hal ini menunjukkan bahwa perlakuan biofungisida dan perlakuan pembanding mampu menekan perkembangan JAP dan/atau menurunkan skala serangan.

Tabel 5. Perkembangan intensitas serangan penyakit JAP sampai dengan 9 bulan setelah perlakuan (bsp)

Table 5. Development of WRD disease intensity until 9 months after treatments (mat)

\begin{tabular}{|c|c|c|c|c|c|c|}
\hline \multirow{3}{*}{ No. } & \multirow{3}{*}{$\begin{array}{l}\text { Perlakuan } \\
\text { Treatments }\end{array}$} & \multicolumn{4}{|c|}{$\begin{array}{c}\text { Intensitas serangan penyakit* } \\
\text { Disease intensity* } \\
(\%)\end{array}$} & \multirow{3}{*}{$\begin{array}{c}\text { Perubahan } \\
\text { intensitas serangan } \\
\text { penyakit ** } \\
\text { Decrease/Increase } \\
\text { of Disease Intensity } \\
(\%)\end{array}$} \\
\hline & & $0 \mathrm{bsp}$ & $3 \mathrm{bsp}$ & $6 \mathrm{bsp}$ & $9 \mathrm{bsp}$ & \\
\hline & & O mat & 3 mat & $6 \mathrm{mat}$ & 9 mat & \\
\hline 1 & Biofungisida $20 \mathrm{~g} / \mathrm{ph}$ & $33,33 a$ & $33,33 b$ & $15,00 b$ & $10,00 \mathrm{~b}$ & $(-) 23,33$ \\
\hline 2 & Biofungisida $40 \mathrm{~g} / \mathrm{ph}$ & $26,67 a$ & $25,00 \mathrm{~b}$ & $10,00 b$ & $8,33 b$ & $(-) 18,34$ \\
\hline 3 & Biofungisida $100 \mathrm{~g} / \mathrm{ph}$ & $33,33 a$ & $30,00 b$ & $13,33 b$ & $11,67 \mathrm{~b}$ & (-) 21,66 \\
\hline 4 & Biofungisida $200 \mathrm{~g} / \mathrm{ph}$ & $35,00 a$ & $30,00 \mathrm{~b}$ & $15,00 \mathrm{~b}$ & $13,33 b$ & (-) 21,67 \\
\hline 5 & Biofungisida $400 \mathrm{~g} / \mathrm{ph}$ & $35,00 a$ & $33,33 b$ & $18,33 b$ & $16,67 \mathrm{~b}$ & $(-) 18,33$ \\
\hline 6 & Triadimenol $5 \mathrm{~g} / \mathrm{ph}$ & $36,67 a$ & $33,33 b$ & $15,83 b$ & $10,83 \mathrm{~b}$ & (-) 25,84 \\
\hline 7 & Triadimefon $5 \mathrm{cc} / \mathrm{ltr}$ & $37,50 \mathrm{a}$ & $33,33 b$ & $21,67 b$ & $20,83 b$ & (-) 16,67 \\
\hline 8 & Trichoderma $100 \mathrm{~g} / \mathrm{ph}$ & $30,83 a$ & $36,67 b$ & $25,83 b$ & $26,67 \mathrm{~b}$ & $(-) \quad 4,16$ \\
\hline 9 & Kontrol & $37,50 a$ & $48,33 a$ & $60,00 a$ & $64,17 \mathrm{a}$ & (+) 26,67 \\
\hline
\end{tabular}

* Angka-angka yang diikuti huruf yang sama tidak berbeda nyata menurut uji Jarak Berganda Duncan pada taraf 5\%

* Values followed by the same letter are not significantly different according to Duncan Multiple Range test at 5\% level

** $(-)=$ intensitas serangan penyakit turun (ada proses penyembuhan atau ada penurunan skala serangan)

$(+)=$ intensitas serangan penyakit naik (serangan semakin parah atau skala serangan naik)

** (-) = decrease in disease intensity (less severe attack)

$(+)=$ increase in disease intensity (more severe attack) 
Perubahan intensitas penyakit dari setiap pengamatan pada perlakuan berbagai dosis biofungisida dibandingkan dengan perlakuan fungisida pembanding tidak berbeda nyata. Semua perlakuan biofungisida memiliki penurunan intensitas serangan penyakit yang lebih tinggi dibandingkan perlakuan fungisida pembanding triadimefon dan Trichoderma spp. Pelakuan fungisida kimia triadimenol memiliki penurunan intensitas serangan penyakit lebih tinggi, namun secara statistika tidak berbeda nyata dengan perlakuan biofungisida.

Dari beberapa dosis biofungisida yang digunakan, perlakuan biofungisida dengan dosis $20 \mathrm{~g}$ per pohon mengalami penurunan intensitas serangan penyakit yang lebih tinggi dibandingkan perlakuan biofungisida lainnya. Namun penurunan intensitas serangan penyakit dari beberapa perlakuan tersebut tidak berbeda nyata dengan kisaran 18,33 - 23,33\%. Dari data tersebut menunjukkan bahwa aplikasi biofungisida pada TBM di lapangan terbukti dapat menurunkan intensitas serangan penyakit.

Spesies cendawan Trichoderma berhasil digunakan sebagai bahan aktif atau agensia biofungisida karena dapat tumbuh dengan cepat, memiliki kemampuan reproduksi yang tinggi, menghambat patogen, memiliki beberapa mekanisme antagonis, memiliki daya saing yang baik di rizosfer, toleran atau resisten terhadap fungisida tanah, memiliki kemampuan untuk bertahan hidup dalam kondisi yang tidak menguntungkan, efisien dalam memanfaatkan nutrisi tanah, memiliki agresivitas yang kuat terhadap cendawan patogen, dan juga meningkatkan pertumbuhan tanaman (Jayasuriya dan Thennakoon, 2007; Vinale et al., 2006).

\section{KESIMPULAN}

Berdasarkan hasil serangkaian kegiatan penelitian, baik skala laboratorium, rumah kaca, maupun lapangan, maka dapat disimpulkan hal-hal sebagai berikut:

1. Pengujian secara in vitro di laboratorium membuktikan bahwa biofungisida efektif menekan perkembangan $R$. microporus, dengan rata-rata penghambatan terhadap R. microporus sebesar 57,62\%.

2. Pada pengujian di rumah kaca dengan menggunakan bibit karet dalam polibeg, perlakuan biofungisida $100 \mathrm{~g}+$ pupuk hayati $200 \mathrm{~g}$ cukup efektif menghambat perkembangan JAP dengan penurunan intensitas serangan penyakit JAP sebesar $5,56 \%$, meskipun efektivitasnya lebih rendah dibanding fungisida kimia. Namun, perlakuan biofungisida + pupuk hayati tersebut mampu meningkatkan pertumbuhan tanaman yang tercermin dari pertumbuhan akar yang lebih lebat dan tanaman yang lebih tinggi, serta biomassa kering tanaman yang lebih berat dibandingkan perlakuan lainnya.

3. Pengujian biofungisida pada TBM di lapangan menunjukkan bahwa biofungisida efektif menekan JAP, dengan penurunan intensitas serangan penyakit JAP sebesar 18,33 sampai dengan $23,33 \%$. Perlakuan biofungisida 20 $\mathrm{g} /$ pohon memiliki penurunan intensitas serangan penyakit JAP yang lebih tinggi dibanding perlakuan biofungisida lainnya. Hal ini tidak berbeda nyata dengan fungisida kimia pembanding.

4. Pengujian biofungisida berbasis mikroorganisme antagonis pada skala laboratorium, rumah kaca, dan lapangan ini masih terbatas sehingga masih membutuhkan pengamatan lebih lanjut.

\section{UCAPAN TERIMA KASIH}

Terima kasih kami ucapkan kepada PT. Biotrack Technology Indonesia atas kerjasamanya yang baik dalam penyediaan sarana penelitian biofungisida.

\section{DAFTAR PUSTAKA}

Agrios, G. N. 2005. Plant Pathology. Elsevier Academic Press, London.

Amaria, W., E. Taufiq,, dan R. Harni. 2013. Seleksi dan Identifikasi Jamur Antagonis Sebagai Agens Hayati Jamur Akar Putih (Rigidoporus microporus) pada Tanaman Karet. Buletin RISTRI4(1): 1-8. 
Benitez, T., A. M. Rincon, M. C. Limon., and A. C. Codon. 2004. Biocontrol Mechanisms of Trichoderma strains. International Microbiology 7: 249-260.

Cook, R. J. and K. F. Baker. 1983. The Nature and Practice of Biological Control of Plant Patogen. The American Phytopathological Society, USA.

Fairuzah, Z. dan Karyudi. 2010. Effectiveness of Biofungicide Triko $\mathrm{SP}^{\text {plus }}$ in Controlling White Root Disease. Proceedings International Workshop on White Root Disease of Hevea Rubber New Directions and Strategies in Management. Sri Lanka, 14-16 Desember.

Fairuzah, Z., C. I. Dalimunthe., Karyudi, S. Suryaman., dan W. E. Widhayati. 2014. Keefektifan Beberapa Fungi Antagonis (Trichoderma sp.) Dalam Biofungisida Endohevea terhadap Penyakit Jamur Akar Putih (Rigidoporus microporus) di Lapangan. Jurnal Penelitian Karet 32(2): 122138.

Gaur, A. and A. Adholeya. 2004. Prospect of Arbuscular Mycorrhizal Fungi in Phytoremediation Of Heavy Metal Contaminated Soils. Current Science 86(4): 528-534.

Gavrilescu, M. and Y. Chisti. 2005. Biotechnology A Sustainable Alternative for Chemical Industry. Biotechnology Advances 23: 471-499.

Hart, M. M. and J. T. Trevors. 2005. Microbe Management: Application of Mycorrhyzal Fungi in Sustainable Agriculture. Frontiers in Ecology and the Environment 3(10): 533-539.

Jayasinghe, C. K. 2011. White Root Disease, The Most Devastating Root Disease of the Rubber Tree. International Rubber Research and Development Board, Malaysia.

Jayasuriya, K. E. and B. I. Thennakoon. 2007. Biological Control of Rigidoporus microporus, the cause of white root disease in rubber. Cey. J. Sci. (Bio. Sci.) 36(1): 9-16.
Kaewchai, S., K. Soytong, and K. D. Hyde. 2009. Mycofungicides and Fungal Biofertilizers. Fungal Diversity 38: 2550 .

Khetan, S.K. 2001. Microbial Pest Control. Marchel Dekker, New York.

Liu, X., J. Pang., and Z. Yang. 2009. The Biocontrol Effect of Trichoderma and Bacillus subtilis SY1. Journal of Agricultural Science 1(2): 132-136.

Mattjik, A. A. dan M. Sumertajaya. 2006. Perancangan Percobaan dengan Aplikasi SAS dan Minitab. Institut Pertanian Bogor Press, Bogor.

Morsy, E. M., K. A. Abdel-Kawi., dan M. N. A. Khalil. 2009. Efficiency of Trichoderma viridae and Bacillus subtilis as Biocontrol Agents Gainst Fusarium solani on Tomato Plants. Egypt. J. Phytopathol. 37(1): 47-57.

Muharni dan H. Widjajanti. 2011. Skrining Bakteri Kitinolitik Antagonis Terhadap Pertumbuhan Jamur Akar Putih (Rigidoporus lignosus) dari Rizosfir Tanaman Karet. Jurnal Penelitian Sains 14(1): 51-56.

Rahayu, S., S. Pawirosoemardjo., and Sujatno. 2007. Biological Control of White Root Disease of Hevea Rubber Using Trichoderma-Bas ed Biofungicide Triko $\mathrm{SP}^{\text {plus }}$. Proceedings International workshop on White Root Disease of Hevea Rubber. Salatiga, 2829 November.

Setyawan, B., S. Pawirosoemardjo., dan H. Hadi. 2013. Biofungisida Triko Combi sebagai Salah Satu Pengendali Jamur Akar Putih pada Tanaman Karet. Warta Perkaretan 32(2): 83-94.

Sinaga, M. S. 2006. Dasar-Dasar Ilmu Penyakit Tumbuhan. Penebar Swadaya, Jakarta.

Situmorang, A. 2004. Status dan Manajemen Pengendalian Penyakit Akar Putih di Perkebunan Karet. Prosiding Pertemuan Teknis Strategi Pengelolaan Penyakit Tanaman Karet untuk Mempertahankan Potensi Produksi Mendukung Industri Perkaretan Indonesia Tahun 2020. Palembang, 6-7 Oktober. 
Situmorang, A. dan A. Budiman. 2003. Penyakit Tanaman Karet dan Pengendaliannya. Balai Penelitian Sembawa, Palembang.

Situmorang, A. dan H. Suryaningtyas. 2007. Enhancing the Decay of Rubber Stump by Using Wood-Decay Fungi in Control of White Root Disease. Proc. Int. Rubb. Conf. Bali, 13-15 Juni.
Vinale, F., K. Sivasithamparam, E. L. Ghisalberti, R. Marra, S. L. Woo., and M. Lorito. 2008. Trichoderma Plant Pathogen Interactions. Soil Biology \& Biochemistry 40: 1-10.

Yeasmin, T., P. Zaman, A. Rahman, N. Absar, dan N.S. Khanum. 2007. Arbuscular Mycorrhizal Fungus Inoculum Production in Rice Plants. African Journal of Agricultural Research 2(9): 463-467. 